\title{
Versailles, Courtesans, and the Hameau de la Reine \\ How the opulence of the French Nobility con- tributed to the Revolution
}

Hayley Parsons 
The extravagance of the French courts of Louis XIV (r. 1643-1715), Louis XV (r. 1715-1774), and his grandson, Louis XVI (r. 1774-1793) was a significant factor leading up to the French Revolution (1789-99) and the toppling of the monarchy. Even in the modern era Marie Antoinette and Versailles exemplify excess. French nobles have had a long history of being trendsetters and fashion icons but appear to have reached their zenith of influence from the mid 17th century until the outbreak of the Revolution. The beginning of the over-the-top nature of the Bourbon court started with Louis XIV moving the nobility and courtiers out of Paris to the enormous new palace of Versailles. After the death of Louis XIV came the rule of Louis XV who spent vast sums of the kingdom's treasury on his mistresses; namely Madame du Pompadour, and Madame du Barry. Following his death, Louis XVI and his wife, the infamous spendthrift, Marie Antoinette, were crowned King and Queen of France.

The Court's love for all things beautiful helped create a society obsessed with appearances and material goods. It could even be argued that Paris' reputation for being the most influential fashion centre in the modern era is because in pre-Revolutionary years, the French nobles were the best dressed and set trends all over the known world. But, as time progressed, the lower to middle class citizens became increasingly disturbed by the careless spending of the royals and living within a society which allowed those without any merit to hold positions of great power as long as they had the proper connections and status from birth. The Bourbon reign ended with the 'Bloody revolution'; a reaction against the decadent royals and their poor governance.

Louis XIV, son of Louis XIII and Anne of Austria, was a paranoid and suspicious man (for good reason). Louis XIII hated his children and wife and constantly threatened to take the children away from Anne, even forcing Louis, the Dauphin, to beg his father's forgiveness so that he would not be sent away from his mother ${ }^{1}$. After the death of Louis XIII, Louis XIV was too young to rule as king but his mother, Anne

\footnotetext{
${ }^{1}$ Richard Wilkinson, Louis XIV (Abingdon, Oxon: Routledge, an imprint of the Taylor \& Francis Group, 2018), 15
} 
reigned as regent. The Fronde, a series of civil wars in France between 1648-1653 pitted the French nobility (lead by Gaston of Orleans, The Grande Conde, and Armand de Bourbon) against the Queen, young Louis, and Cardinal Mazarin. ${ }^{2}$ This turbulent period ended with the creation of an absolute monarchy and shaped the way that Louis XIV ruled. The Fronde taught Louis to be very cautious of those surrounding him and prompted him to mke changed within court.

The small royal hunting lodge built of brick and stone in the fiefdom of Versailles, became the famed palace under the rule of Louis XIV. Louis seemed to have taken a liking to the site of Versailles when in 1651, he made a hunting excursion into the forests surrounding the lodge. ${ }^{3}$ The years of The Fronde, leaving a lasting impression on Louis, caused him to have a deeply rooted distrust in the nobility. Versailles was the perfect place to move his court and ultimately to centralize the monarchy. It was just far enough outside of Paris that Louis could keep surveillance on all of the members of his court quite easily but close enough that labourers, artists, and all those involved in keeping the Court running could make the 14 mile jaunt from Paris in a reasonable amount of time.

The rebuilding of Versailles began in 1661 under the architect, Louis le Vau. ${ }^{4}$ It was not completed util 1715; the year of Louis XIV's death. Some of the most celebrated artists and architects in France during the period of Versailles' expansion worked in this massive project. Charles le Brun, portraitist of the king, interior decorator, and father of the favourite portraitist of Marie Antoinette, Elisabeth Vigee le Brun, was in charge of the interiors. Jules Hardouin-Mansart, the extraordinary royal architect, created the Hall of Mirrors and the trendsetting landscape architect, Andre le Notre, developed the vast gardens of Versailles, influencing French gardening for years to come. Having employed such great names in design, Versailles was destined to be a palace of grandeur and great expense. By the end of its construction, Versailles could

\footnotetext{
${ }^{2}$ Wilkinson, Richard. Louis XIV. 17

3 “History", Palace of Versailles, February 08, 2018, accessed March 02, 2018, http://en.chateauversailles.fr/discover/ history\#the-reign-of-louis\%C2\%A0xiv1638\%C2\%A0-1715.

${ }^{4}$ Robert W. Berger, Versailles: The Chateau of Louis XIV (New York: College Association of America, 1985), 5.
} 
hold as many people as a small town (20,000 people)! At any time an estimated 3,000 people were housed at Versailles; courtiers, professional courtesans, servants, and the nobility made up its inhabitants. ${ }^{5}$

The modernization and enlargement of Versailles was unsurprisingly, extremely expensive. During Louis XIV's reign public records were kept on the monarch's spending on building works. Over 71 thousand livres was spent on the masonry alone. ${ }^{6}$ To put this into a modern perspective, one French livres tournais, the currency used during the reign of Louis XIV, is estimated to be the equivalent of 15 American dollars. ${ }^{7}$ While it is almost impossible to figure out how much money Versailles would be worth in today's currency because of the ever changing value of money, experts have estimated Versailles's value from 2 billion USD (in 1994) up to $\$ 299,520,000,000$. Between 6-25\% of the treasury's money was spent annually on just the upkeep and day-to-day runnings of Versailles. ${ }^{8}$

While most people in the modern age will know Louis XIV as the builder of Versailles, or as the glamorous 'Sun King', they do not realize that outside of the glamorous upper crust society, Louis' France was a brutal place to live. The last three decades of Louis' reign were terrible for the commoners. ${ }^{9}$ A recession occurred throughout Europe which caused shortage of coinage, declining wages, decrease in trade, and inflation. On top of the economic crisis, a series of bad harvests left the common people malnourished and starving. It was reported that corpses lining the roads were found with grass in their mouthes and pet horses, cats, and dogs were eaten for survival. ${ }^{10}$ During these years vagrancy became an increasing issue in larger centres like Paris and Strasbourg. The treasury's coffers had run low and to replenish them Louis and his ministers increased taxes enormously. The taille caused commoners to hide their money from tax

\footnotetext{
5 “Marie Antoinette and the French Revolution” PBS. September 13, 2006. Accessed March 02, 2018. http://www.pbs.org/ marieantoinette/life/index.html.

${ }^{6}$ Robert W. Berger, Versailles: the Chateau of Louis XIV. 7.

${ }^{7}$ Rodney, Edvisson. “Historical Currency Converter (test version 1.0).” Historical Currency Converter. January 10, 2016. Accessed March 06, 2018. http://www.historicalstatistics.org/Currencyconverter.html.

8 “Marie Antoinette and the French Revolution” PBS. September 13, 2006. Accessed March 02, 2018. http://www.pbs.org/ marieantoinette/life/index.html.

${ }^{9}$ Richard Wilkinson, Louis XIV, 226.

${ }^{10}$ Richard Wilkinson, Louis XIV, 227.
} 
collectors while the rich continued to throw lavish parties and spend money. The poor state of affairs created a sense of mistrust in the government and nobles by the commoners.

Louis XIV's greatest achievement as a ruler was creating a new monarchy in which no-one could question his authority. Louis did so by making sure that he had the most lavish, and strictly run court in Europe. But, in order to garner his much needed respect, and possibly the noble's fear, Louis had to spend gargantuan amounts of money to fund his various building projects and fripperies. In turn, this encouraged an overindulgent aristocracy that lasted up until the French Revolution.

"Louis XV has [the] extremely good heart; he is human, gentle, affable, sympathetic, fair." authoritarian great-grandfather, louis XV was soft and often had others rule France through him; mostly Cardinal de fleury and official mistress of the King, Madame du Pompadour. Louis XV's reign was largely unsuccessful. In the latter part of his reign, famine swept across France, "so fatal were ravages of famine that in Limosin and Marche only, four thousand persons are supposed to have perished."12 Louis also incurred an enormous amount of debt from wars and spending lavishly on his mistresses.

For a period of time, Louis left Versailles to live closer to Paris in the palace of Vincennes. He later returned to Versailles but was uncomfortable with the very public traditions of his great-grandfather. Louis was a timid man and created a much more private Versailles. This did not mean however, that the court of Louis XV would be any less extravagant than his predecessor's.

Louis was fond of holding balls in the Hall of Mirrors and having plays performed in his new built theatre. During a ball which was being held to celebrate the marriage of Dauphin Louis-Ferdinand, king Louis met Jeanne-Antoinette Lenormant d'Etiolles nee Poisson. She was born into a bourgeoisie family; the daughter of the director of military provisions. At the ball, Jeanne-Antoinette caught the attention of the King and was made mistress shortly after. Louis had his new mistress installed in the apartments di-

\footnotetext{
${ }^{11}$ Pompadour, Jeanne Antoinette Fish, Marchioness, 1721-1764, Memoirs of Madame de Pompadour: where we discover motives for wars, and treaties of peace, embassies, negotiations in different courts of Europe; secret pursuits and intrigues, the character of generals, that of ministers of state, the cause of their elevation, and the subject of their disgrace; and generally all that has happened more remarkable at the court of France during the twenty-last years of the reign of Louis XV., vol.1 (Liege, Belgium, 1766). 13, accessed March 04, 2018, https://archive-org.login.ezproxy.library.ualberta.ca/stream/cihm_4004/cihm_40045_djvu.txt.

12 John Adams, The History of France, From the First Establishment of That Monarchy to the Present Revolution. In Two Volumes., vol 2, 2 vols. (Dublin 1791), 316, accessed March 16, 2018, http:/find.galegroup.com.login.ezproxy.library.ualberta.ca/ ecco/retrieve.do?
} 
rectly above his and in 1745, made her the Marquise de Pompadour. Louis was so besotted by her that he had the Petit Trianon (later Marie Antoinette's private party headquarters) built for the Marquise. During her time at court up until her death in 1764 , the Marquise is estimated to have spent 35,924,140 livres and owned many properties including: Petit Trianon, Châteaux de Pompadour, de Choisy, de la Muette, de Bellevue, de Champs, and de Menars. ${ }^{13}$ According to Forbes, the restored Chateau de Menars was worth 100 million USD in 2013. Pompadour is said to have been one of the most expensive mistresses of the ancien regime ${ }^{14}$.

Unlike the Marquise de Pompadour, Louis' next Maître en Titre ${ }^{15}$ was not interested in state affairs. Madame du Barry cared for nothing but jewels and beautiful clothing. Du Barry was hated by both the commoners and aristocrats (especially by the then Dauphine, Marie Antoinette, who would snub the royal mistress at every possible opportunity). The middle and lower classes hated du Barry for her outlandish spending habits and the King's obsession with her, "The monarch, immersed in sensuality, heard with indifference the cries of his people but listened with more respect to the solicitations of his mistress, the Countess du Barri."16 The aristocrats found du Barry vile due to her low birth. The Comtesse, born Jean Becu, was the bastard child of a peasant woman and a priest. Du Barry had little political influence and her popularity contributed to the decline in the French crown's reputation.

Louis spent an astonishing amount of money on his new mistress. In 1772, he commissioned the jewellers Boehler and Bassanger to create a necklace that exceeded all others in expense, and beauty. ${ }^{17}$ This necklace, the very same that sparked the "Affair of the Diamond Necklace" in which Marie Antoinette was involved, was estimated to have cost 2 million livres at the time of its creation and weighed 28,000

\footnotetext{
13 Stamberg, Susan. "More than a Mistress: Madame de Pompadour was a Minister of the Arts" NPR. May 10, 2016. Accessed March 04, 2018. https:/www.npr.org/2016/05/10/477369874/more-than-a-mistress-madame-de-pompadour-was-a-mistress-ofthe-arts.

${ }^{14}$ Ancient regime

15 Title given to the official mistress of the King

16 John Adams, The History of France, from the First Establishment of That Monarchy to the Present Revolution. In Two Volumes,. Vol.2, 2 vols. (Dublin, 1791), 316.

${ }^{17}$ Lear, Professor Andrew. “Courtesans and Royal Mistresses: Madame du Barry.” New York City Art Museum Tours. October 25, 2016. Accessed March 06, 2018. https://www.shadyladiestours.com/courtesans-and-royal-mistresses-madame-du-barry/.
} 
carats. ${ }^{18}$ Despite the large monthly sum king Louis gave du Barry, she was constantly insolvent; at one point she had been 300,000 livres in debt. ${ }^{19}$

When Louis died in 1774, du Barry was immediately banished from court and sent to an abbey to live with nuns upon the orders of the new King and Queen, Louis XVI, and Marie Antoinette. Though du Barry was banished, she was still obsessed with materiality and money. During the revolution, du Barry fled to London but returned to France to retrieve "two diamonds valued at two millions which [I] had buried in a safe spot in the woods near Saint-Germain" as well as, "silver and gold place settings, diamond necklaces, thousand of gold coins, pearls, and emeralds. ${ }^{20}$ In doing so, the Comtesse sealed her fate and was arrested by the tribunal and beheaded. The public never forgave her for outrageous spending and the lifestyle she represented.

The reign of Louis $\mathrm{XV}$ is not memorable for the things that he or his government achieved. He cared more for his mistresses than he did for the common people and his conduct with du Barry left a stain on the Crown. John Adams wrote of Louis XV, "Lewis XV, who at length fell a victim to those sensual appetites, in the gentrification of which he had sacrificed his own fame and the welfare of his subjects." 21 Louis XVI, a weak ruler more interested in tinkering with clocks and door locks than governing, and Marie Antoinette, or "Madame Deficit", as she would later be called by the commoners, began their reign innocently enough. Marie Antoinette was initially the sweetheart of France and was adored by the masses. But, ignoring the financial trouble Louis XV had left the new monarchs, Antoinette continued with the frivolities she had enjoyed when she was Dauphine living at Louis XV's court. The new Queen was either oblivious or simply did not care about what was happening outside of Versailles; poor harvests struck the nation and continued throughout the reign of Louis XVI due to the 'Little Ice Age' which did not end until

\footnotetext{
18 The Editors of Encyclopaedia Britannica. “Affair of the Diamond Necklace.” Encyclopaedia Britannica. August 18, 2017. Accessed March 05, 2018. https://www.britannica.com/event/Affair-of-the-Diamond-Necklace.

${ }^{19}$ Eleanor Herman, Sex With Kings: 500 years of adultery, power, rivalry, and revenge (New York: Barnes and Noble, 2011), 146.

${ }^{20}$ Will Bashor, Marie Antoinette's Head: The Royal Hairdresser, the Queen, and the Revolution (Guildford, Connecticut: Lyons Press, 2013), 204.

${ }^{21}$ John Adams, The History of France, from the First Establishment of That Monarchy to the Present Revolution. In Two Volumes,. Vol.2, 2 vols. (Dublin, 1791), 320.
} 
1860. In addition to failed harvests, Louis continued to add to the nation's debt by sending troops and money to the American army to support their revolution against the British which proved ironic.

Marie Antoinette's name is synonymous with extravagance. The French queen was a trendsetter and made towering coifs and over-the-top fashion vogue. During a ball held by the monarchs in 1774, Marie Antoinette noticed that very few of the attendees were wearing the latest fashions. In an effort to inform the populace on how to dress, the Queen had her Royal Hairdresser, Leonard Autie, reintroduce the fashion publication Journal de Dames. ${ }^{22}$ The publications' latest revival under the Queen was a success and soon fashionable Parisian women were copying the outfits and coifs pictured in the magazine. In the same year, the famous poufs worn by Marie Antoinette came into existence. Leonard first created the dramatic style for the Duchess of Chartres. According to the historian, Will Bashor, the Duchess's pouf was composed of, "fourteen yard of gauze and numerous plumes waving at the top of the tower." 23 Soon after its conception, the great hairstyle was copied by none other than the Queen of France herself. Antoinette took the pouf to new extremes and added things like model ships, fruit, and bird cages to adorn her hair. Women copied the Queen's even more extravagant style and soon a rule had to be put in place at opera houses restricting the height of said poufs as attendees could not see around the heads of these women. Although these ridiculous coifs were at the height of fashion (literally), they were an inappropriate, and insensitive choice of style. During a time where flour was becoming scarce, the wigs and towering poufs worn by the rich were powdered with large amounts of wheat flour. ${ }^{24}$

During the reign of Louis XV, the Petit Trianon was given to Madame de Pompadour and then Madame du Barry. Marie Antoinette had always had a liking for Trianon and was granted its ownership by her husband, the King. The Queen began spending most of her time away from the court and her husband and spending it at her newly acquired property. The galas and parties held by the Queen at Trianon became legendary due to their lavishness. Because of the herculean sums Marie Antoinette spent on hosting par-

\footnotetext{
${ }^{22}$ Will Bashor, Marie Antoinette's Head: The Royal Hairdresser, the Queen, and the Revolution, 63.

23 Ibid.

24 Galke, Laura. “Perukes, Pomade, and Powder. Hair Care in the 1700s.” Lives \& Legacies. January 23, 2015. Accessed March 12, 2018. https:///ivesandlegaciesblog.org/2015/01/28/perukes-pomade-powder/.
} 
ties at Trianon the King's ministers reproached the Queen for aggravating the treasury's debt. Her behaviour at Petit Trianon is what earned her the nickname, "Madame Deficit". 25

In an attempt to better her image the Queen made a trip into Paris to greet the people who had once adored her. Instead of cheering and applauding they were cold and unreceptive. Because she had been spending the majority of her time in private at Petit Trianon Antoinette genuinely believed that the public was angry at her for becoming more secluded and not because she was a flamboyant spendthrift. To make matters even worse for herself, the Queen purchased the chateau at St. Cloud in order to be closer to her subjects; of course this made the people even angrier. As the people continued to starve, the Queen bought another extravagant property.

During the 1780s Marie Antoinette became fascinated with peasant culture. The Queen cast aside her grand habits de cour ${ }^{26}$ with their large, uncomfortable panier and the day-to-day robe a francaise ${ }^{27}$ (bedecked in precious stones, beads, and ruffles) and instead dressed like an idealized peasant wearing simple muslin dresses called, robe en Gaulle. ${ }^{28}$ Hairstyles also became much more simple and the wax figures, ostrich plumes, and precious jewels that once adorned huge poufs were cast aside and traded in for widely brimmed, straw hats.

To go with her newfound passion for farming and rural living, Marie Antoinette had a model hamlet built on the grounds of Versailles, Hameau de la Reine. The hamlet contained a working dairy, decorative windmill, chicken coops, fisherman's cottage, guest cottages, and a guard tower. ${ }^{29}$ The supposedly rustic cottages were richly decorated for her guests. Like her purchase of St. Cloud, the Queen's hamlet was also viewed by the public as repulsive. Peasants were irate at the thought of the nobility playing at being farmers while they toiled in the fields just to scrape by.

\footnotetext{
${ }^{25}$ Will Bashor, Marie Antoinette's Head: The Royal Hairdresser, the Queen, and the Revolution, 74-75.

${ }^{26}$ Gowns worn by aristocratic women for formal occasions

27 'Casual' day dresses

28 “Fashion at Versailles.” Palace of Versailles. September 25, 2017. Accessed March 13, 2018. https://en.chateauversailles.fr/ news/life-estate/fashion-versailles\#the-project.

29، The Queen's Hamlet.” Palace of Versailles. March 01, 2017. Accessed March 13, 2018. https://en.chateauversailles.fr/discover/estate/estate-trianon/queen-hamlet.
} 
Not to be forgotten, the palace of Fontainebleau, located close to Paris, was also a place where Louis XVI and his family occasionally chose to reside. Its extravagance almost equalled that of Versailles'. During her reign, Marie Antoinette commissioned mass renovations of the palace. Included in the plans were her famed Silver Boudoir, a new theatre, and a total makeover of the Queen's bedroom. Famously, the bed specially made for Marie Antoinette was so intricately decorated and finely detailed that it was not completed until 1797, four years after she had been executed.

During the 1780s courtly life at Fontainebleau had reached its zenith; the infamous Minister of Foreign Affairs during the ancien regime, Talleyrand, remarked to the 19th century French Prime Minister, Guizot, "Those who have not lived through the years around 1789 cannot know what is meant by the pleasure of life." 30

For years the people of France had been left starving by poor harvests and had been taxed heavily to support the French army and to support the runnings of the Court. Louis XVI was a clueless, weak, pushover who let his wife drain the treasury of any money. The French people were fed up with the carelessness of the government and its poor treatment of the people. Marie Antoinette was an easy target for slander as she continued to throw lavish events to entertain her glamorous friends, spend on clothing and buy up more properties.

The French Revolution was caused by many factors: the Third Estate's lack of representation in the government, the dismissal of the beloved Minister of Finance, Jacques Necker, and of course, the financial ruin of the country. The over-the-top opulence of the Court, beginning with Louis XIV, destroyed any financial security that France had and it became a burden that the lowest classes were forced to carry. Ignoring the grumblings of its destitute subjects, the French nobility continued to party, build mansions, and gamble money away; heaping onto the debt of the Crown. Though the French nobility, like all nobility had always been extravagant, the Court reached new heights under Louis XIV. Louis XIV originally created Versailles as a way to centralize the monarchy and to show the French people the King's power after years of civil war and turmoil. As time passed, the nobles became accustomed to the incredibly sumptuous lifestyle created by the Sun King thus following a pattern of debt.

\footnotetext{
30 "The 18th Century” Château de Fontainebleau. Accessed March 13, 2018. https://www.musee-chateau-fontainebleau.fr/
} The-18th-Century?lang=en. 
It is important to understand that the extravagance of the French monarchy was a pattern started by Louis XIV as a reaction to his traumatic life. The long reigns of both Louis XIV, and XV put enormous financial strains on the country. By the time Louis XVI and Marie Antoinette came into power, France's coffers were already empty but the nobles kept spending. The already established contempt towards the nobility turned into animosity during the final years of the ancien regime as a result of the lack of care shown to the public while they were in dire straits. It was ineptitude of the government and vast amounts of money squandered by the nobles that led to the events known as the French Revolution, and the overthrowing of the monarchy.

\section{Bibliography}

"A Day in the life of Louis XIV". Palace of Versailles. March 01, 2018. Accessed March 04, 2018. http:// en.chateauversailles.fr/discover/history/day-life-louis-xiv\#evenings.

Adams, John, The History of France, From the First Establishment of That Monarchy to the Present Revolution. In Two Volumes., vol 2, 2 vols. (Dublin 1791), 316, accessed March 16, 2018, http:/find.galegroup.com.login.ezproxy.library.ualberta.ca/ecco/retrieve.do?

Bashor, Will. Marie Antoinette's Head: The Royal Hairdresser, the Queen, and the Revolution. Guildford, Connecticut: Lyons Press, 2013.

Berger, Robert W. Versailles: The Chateau of Louis XIV. New York: College Association of America, 1985. 


\section{Page 11}

Galke, Laura "Perukes, Pomade, and Powder: Hair Care in the 1700s". Lives and Legacies. January 23, 2015. Accessed March 12, 2018. https://livesandlegaciesblog.org/2015/01/28/perukes-pmade-powder/.

Herman, Eleanor. Sex With Kings: 500 Years of adultery, power, rivalry, and revenge. New York: Barnes and Noble, 2011.

Historical Currency Converter. January 10, 2016. Accessed March 02, 2018. http://www.historicalstatistics.org/Currencyconverter.html.

“History” Palace of Versailles. February 08, 2018. Accessed March 02, 2018. http://en.chateauversailles.fr/discover/history\#the-reign-of-louis\%C2\%A0xiv1638\%C2\%A0-1715.

Lear, Professor Andrew. “Courtesans and Royal Mistresses: Madame Du Barry.” New York City Art Museum Tours. October 25, 2016. Accessed March 05, 2018. https://www.shadyladiestours.com/courtesansand-royal-mistresses-madame-du-barry/.

"Marie Antoinette and the French Revolution.” PBS. September 13, 2006. Accessed March 02, 2018. http://www.pbs.org/marieantoinette/life/index.html.

Pompadour, Jeanne Antoinette Fish, Marchioness, 1721-1764. Memoirs of Madame de Pompadour: where we discover motives for wars, and treaties of peace, embassies, negotiations in different courts of Europe; secret pursuits and intrigues, the character of generals, that of ministers of state, the cause of their elevation, and the subject of their disgrace; and generally all that has happened more remarkable at the court of France during the twenty-last years of the reign of Louis XV., vol.1 (Liege, Belgium, 1766). 13, accessed March 04, 2018, https://archive-org.login.ezproxy.library.ualberta.ca/stream/cihm_4004/ cihm_40045_djvu.txt. 
Stamberg, Susan. "More Than A Mistress: Madame De Pompadour Was A Minister Of The Arts.” NPR. May 10, 2016. Accessed March 14, 2018. https://www.npr.org/2016/05/10/477369874/more-than-a-mistress-madame-de-pompadour-was-a-minister-of-the-arts.

The Editors of Encyclopaedia Britannica. "Affair of the Diamond Necklace.” Encyclopaedia Britannica. August 18, 2017. Accessed March 13, 2018. https://www.britannica.com/event/Affair-of-the-DiamondNecklace.

"The 18th Century." Château de Fontainebleau. Accessed March 13, 2018. http://www.musee-chateaufontainebleau.fr/The-18th-Century?lang=en.

Wilkinson, Richard. Louis XIV. Abingdon, Oxon: Routledge, an imprint of the Taylor \& Francis Group, 2018. 